\title{
The relevance of pelagic calcification in the global carbon budget of lakes and reservoirs
}

\author{
Hares Khan 1,2,*iD, Rafael Marcé3,4 (iD), Alo Laas² (iD and Biel Obrador ${ }^{1}$ (iD \\ ${ }^{1}$ Department of Evolutionary Biology, Ecology and Environmental Sciences, Institut de Recerca de la Biodiver- \\ sitat (IRBio), University of Barcelona, Spain. \\ 2 Estonian University of Life Sciences, Institute of Agricultural and Environmental Sciences, Centre for Limnol- \\ ogy, Estonia. \\ 3 Catalan Institute for Water Research, ICRA, Spain. \\ 4 University of Girona, Girona, Spain. \\ * Corresponding author: hkhan@ub.edu
}

Received: $29 / 09 / 20 \quad$ Accepted: 04/12/20

\begin{abstract}
The relevance of pelagic calcification in the global carbon budget of lakes and reservoirs

Calcite precipitation acts as a carbon sink in the sediments and a short-term source of carbon dioxide $\left(\mathrm{CO}_{2}\right)$ to the atmosphere, as widely acknowledged in marine studies. However, pelagic calcite precipitation has received limited attention in lakes. Here we use the relationship between lake water alkalinity and reported calcification rates to provide the first global estimate of pelagic calcification in lakes. Global gross calcification rates amount to $0.03 \mathrm{Pg} \mathrm{C} \mathrm{yr}^{-1}(0.01-0.07)$ comparable to rates of organic carbon burial, whereas its related $\mathrm{CO}_{2}$ release is largely buffered by the carbonate equilibria. Calcification occurs at water alkalinity above $1 \mathrm{meq} / \mathrm{L}$ corresponding to $57 \%$ of global lake and reservoir surface area. Pelagic calcification therefore is a prevalent process in lakes and reservoirs at the global scale, with a potentially relevant role as a sedimentary inorganic carbon sink, comparable in magnitude to the total calcite accumulation rates in ocean sediments.
\end{abstract}

Key words: calcite precipitation, pelagic calcification, carbon cycle, lake carbon budget, carbon fluxes, carbon sink

\section{RESUMEN}

La relevancia de la calcificación pelágica en el balance global de carbono de lagos y embalses

La precipitación de calcita actúa como un sumidero de carbono en sedimentos y una fuente a corto plazo de dióxido de carbono $\left(\mathrm{CO}_{2}\right)$ a la atmósfera, como es ampliamente reconocido en sistemas marinos. Sin embargo, la precipitación pelágica de calcita ha recibido una atención limitada en lagos. Aquí utilizamos la relación entre la alcalinidad del agua y tasas reportadas de calcificación para proporcionar una primera estima global de calcificación pelágica en lagos. Las tasas de calcificación bruta global ascienden a $0.03 \mathrm{Pg} \mathrm{C}$ año-1 (0.01 - 0.07) comparables a las tasas de enterramiento de carbono orgánico, mientras que la consecuente liberación de $\mathrm{CO}_{2}$ está en gran medida amortiguada por los equilibrios de sistema de carbono inorgánico disuelto. La calcificación se produce a alcalinidad superior a $1 \mathrm{meq} / \mathrm{L}$, que corresponde al 57 \% de la superficie global de lagos y embalses. Por lo tanto, la calcificación pelágica es un proceso frecuente en lagos y embalses a escala global, con un rol potencialmente relevante como sumidero de carbono inorgánico sedimentario, comparable en magnitud a las tasas de acumulación total de calcita en los sedimentos oceánicos.

Palabras clave: precipitación de calcita, calcificación pelágica, ciclo del carbono, balances de carbono en lagos, flujos de carbono, sumidero de carbono 
Khan et al.

\section{INTRODUCTION}

Lakes and reservoirs are important components of the continental carbon (C) cycle due to large emissions of methane and $\mathrm{CO}_{2}$ to the atmosphere and burial of organic carbon (OC) in their sediments (Cole et al., 2007; Mendonça et al., 2017; Raymond et al., 2013). OC production, decomposition and burial have been described as the main drivers of C fluxes (Duarte \& Prairie, 2005). Most studies relating $\mathrm{C}$ fluxes to OC metabolism in lakes have been conducted in systems with low water alkalinity (i.e. less than $1 \mathrm{meq} / \mathrm{L}$ ) and high dissolved OC concentrations (McDonald et al., 2013). However, increasing evidence suggests that inorganic carbon (IC) may be equally relevant in lakes of higher alkalinity (Marcé \& Obrador, 2019), comprising $57 \%$ of world's lakes area (Marcé et al., 2015; McDonald et al., 2013). While the role of benthic calcification is acknowledged in such systems, calcification in the pelagic zone is assumed to be negligible due to the rarity of planktonic organisms that produce calcareous shells in freshwaters (Kelts \& Hsü, 1978). However, recent evidences stress the important role of pelagic calcite precipitation in lakes as an alkalinity sink and $\mathrm{CO}_{2}$ source (Müller et al., 2016). This double-edged role is widely acknowledged and quantified in marine studies (Frankignoulle et al., 1994; Ridgwell \& Zeebe, 2005), but its relevance in lakes has been assumed to apply only to saline systems. Evidence suggests that calcification contributes to the large $\mathrm{CO}_{2}$ emissions found in saline lakes, yet those systems represent only a fifth of the Earth's lake surface (Duarte et al., 2008). The biogeochemistry of carbon in saline lakes usually differs from those of freshwater lakes, because of the large carbon pools supporting high $\mathrm{CO}_{2}$ exchange rates and chemical enhancement processes that are usually less relevant in freshwater systems (Duarte et al., 2008). It is therefore necessary to study pelagic calcification in freshwater lakes separately to assess the relevance of this process in these systems representing the vast majority of the Earth's lake surface. Moreover, the majority of freshwater lakes are above the alkalinity threshold of $1 \mathrm{meq} / \mathrm{L}$ where calcification is likely to occur (Khan et al., 2020; Marcé et al., 2015; McConnaughey \& Whelan,
1997). While the occurrence of pelagic calcification in freshwater lakes has often been reported, it has never been quantified at a global scale, nor has its derived $\mathrm{CO}_{2}$ emissions.

High rates of calcite precipitation are often found during the summer season of lakes when calcite saturation peaks due to enhanced primary production that rises the $\mathrm{pH}$ by depleting $\mathrm{CO}_{2}$ concentrations, thereby shifting the carbonic acid equilibrium towards oversaturation of carbonates (Müller et al., 2016). Yet, spontaneous calcification is unlikely to occur, rather it is biologically mediated by picocyanobacteria that provide ideal nucleation sites that further facilitate calcite precipitation in the pelagic zones of lakes (Obst et al., 2009). Calcite precipitation in lakes has been presented as a natural process that can reduce summer eutrophication (Rodrigo et al., 1993). Because of this seasonal association and its occurrence during high primary production, most studies that have quantified calcite precipitation in lakes have focused on the summer season. Using summer pelagic calcification rates from the literature $(n=26$, Supplementary information, available at http://www.limnetica.net/en/limnetica), here we identify a clear association with water alkalinity. Using water alkalinity as the driver variable with obvious mechanistic links with calcification, we provide a first gross global estimate of calcification rates and its derived $\mathrm{CO}_{2}$ emissions. We intentionally excluded rates measured in other seasons than summer or averaged over the year, rates for benthic calcification caused by calcifying macrophytes, rates in brackish systems and saline lakes.

\section{METHODS}

Data on pelagic calcite precipitation was obtained from published literature reporting areal or volumetric rates from either sediment traps, sediment cores, $\mathrm{C}$ or $\mathrm{Ca}^{2+}$ mass balances, incubations, or modelling (Supplementary information, available at http://www.limnetica.net/en/limnetica). Most rates found in the literature are average rates covering only the summer season, therefore we excluded mean annual rates from this analysis. When reported per unit area, areal rates were divided by the mixed layer depth (Zmix) to obtain 


\section{Global Pelagic Calcification in Lakes}

rates per unit volume, assuming that most pelagic calcification occurs in the epilimnion (Hartley et al., 1995; Obst et al., 2009). If Zmix of a specific lake was not specified in the literature, it was calculated using FLAKE Global model (Kirillin et al., 2011). The strong relationship found between alkalinity and calcification rates was used in the upscaling to global rates, using the $5 \%, 50 \%$ and $95 \%$ quantiles to obtain a range of uncertainty. The volumetric rates obtained from this relationship were converted to areal rates by multiplying the volumetric rates with an average Zmix value of 6.72. The average Zmix was calculated from a dataset of 628 lakes (Woolway \& Merchant, 2019), using a hyperbolic function between Zmix and lake fetch (Lewis, 2011). The areal rates by alkalinity level were multiplied by the global surface area of lakes corresponding to each level of alkalinity (alkalinity intervals of $0.05 \mathrm{meq} / \mathrm{L}$ ) (Marcé et al., 2015). The sum of these rates was multiplied by the average number of days of measurements ( 94 days) from which each reported daily rate in the literature was averaged. These calculations are presented in the supplementary Data file.

For upscaling $\mathrm{CO}_{2}$ emissions, the $5 \%, 50 \%$ and $95 \%$ quantiles of the relationship between alkalinity and calcification was used to build a model that simulates the resulting range of lake $\mathrm{CO}_{2}$ partial pressure $\left(\mathrm{pCO}_{2}\right)$ increase at different daily calcification rates that are dependent on the initial alkalinity value. The model is based on the chemical dissolved inorganic carbon (DIC) equilibria whereby 1 mole of calcite that precipitates results in a loss of 1 mole of DIC (because 2 moles of $\mathrm{HCO}_{3}{ }^{2-}$ are lost in the reaction and 1 mole of $\mathrm{CO}_{2}$ is released) and a loss of 2 equiva- a

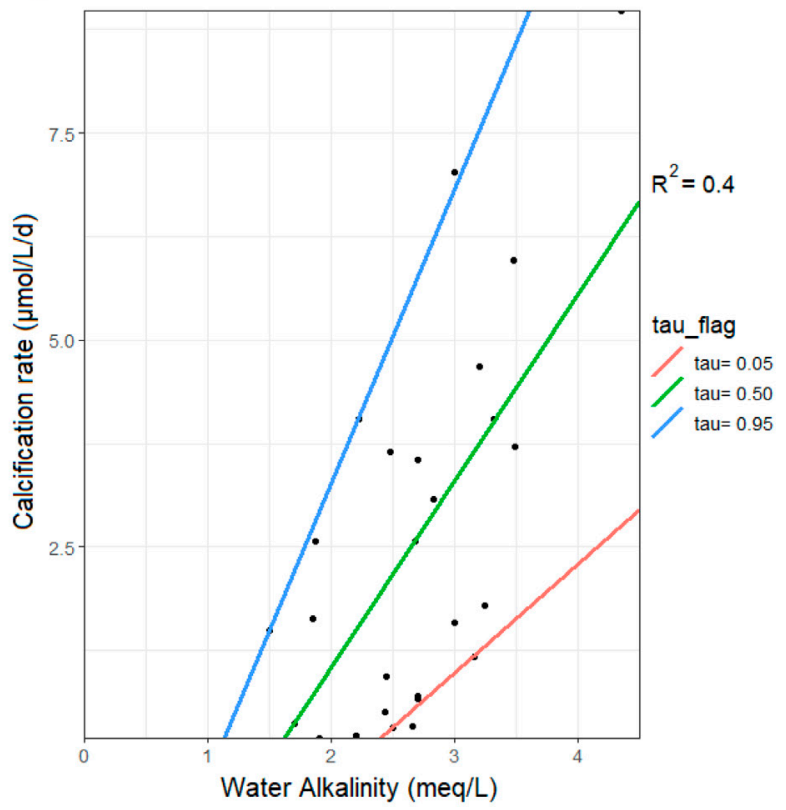

b

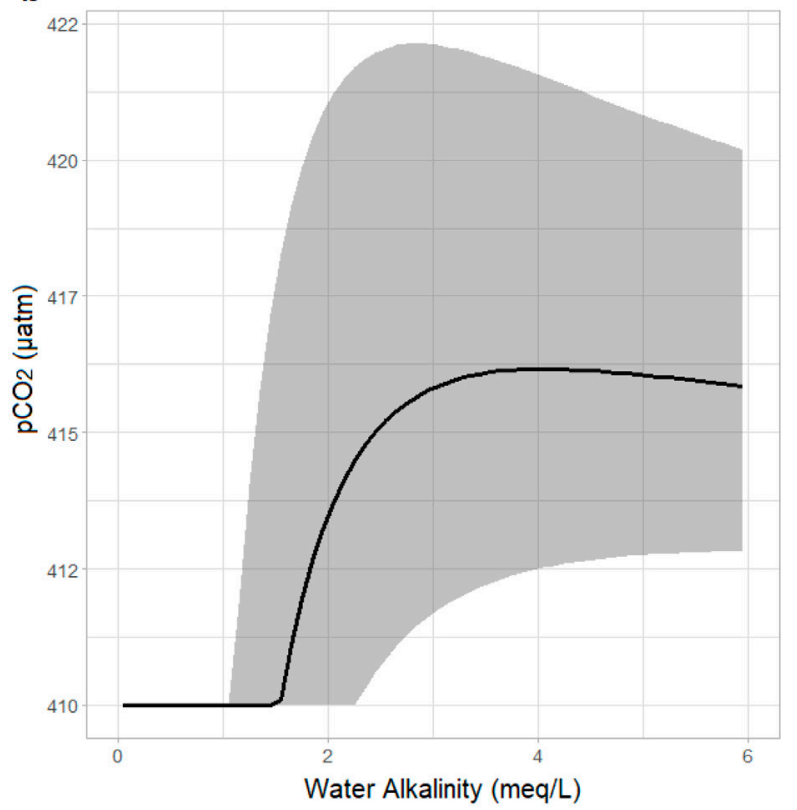

Figure 1. Effects of alkalinity on calcification rates. (a) relationship between alkalinity and calcification rates reported in the literature for global lakes. Lines corresponds to quantile regressions at the $95 \%$ quantile (blue), $50 \%$ (green), and $5 \%$ (red). (b) Daily effect of calcite precipitation on $\mathrm{pCO}_{2}$ at different alkalinity levels. Initial $\mathrm{pCO}_{2}$ value is at atmospheric equilibrium. The solid line represents the $50 \%$ quantile. The shaded area corresponds to the range of calcification found at a given alkalinity level using the 5\% and $95 \%$ quantiles. Efectos de la alcalinidad sobre las tasas de calcificación. (a) relación entre alcalinidad y tasas de calcificación reportadas en la bibliografia para lagos. Las lineas corresponden a regresiones de cuantiles al cuantil $95 \%$ (azul), $50 \%$ (verde) y $5 \%$ (rojo). (b) Efecto diario de la precipitación de calcita sobre la $\mathrm{pCO}_{2}$ a diferentes niveles de alcalinidad. El valor inicial de $\mathrm{pCO}_{2}$ está en equilibrio atmosférico. La línea sólida representa el cuantil $50 \%$. El área sombreada corresponde al rango de calcificación encontrado a un nivel dado de alcalinidad usando los cuantiles del $5 \%$ y $95 \%$. 


\section{Khan et al.}

lents of alkalinity. The fate of the $\mathrm{CO}_{2}$ released by calcification and its interaction with the DIC equilibria is therefore taken into account in this model. The initial $\mathrm{pCO}_{2}$ value was set at the atmospheric equilibrium value of $410 \mathrm{ppm}$. The model is freely available online in the following link (http://hdl.handle.net/2445/172489). The global upscaling was done similarly to the upscaling of calcification rates, using existing data of the global surface area of lakes per alkalinity levels (Marcé et al., 2015). $\mathrm{CO}_{2}$ flux was calculated using Fick's Law of gas diffusion (Millero, 1979) using the global average Piston velocity $\left(\mathrm{k}_{600}\right)$ value of $1 \mathrm{~m} / \mathrm{d}$ with an uncertainty range between 0.74 and 1.33 (Raymond et al., 2013). The sum of the fluxes correspond to the global annual $\mathrm{CO}_{2}$ emissions caused by planktonic calcification. It is a first estimate of the $\mathrm{CO}_{2}$ emissions related to calcification and should therefore be understood as an approximate estimation that can be further refined by research, rather than an ultimate value. All calculations are available in the Supplementary Data File.

\section{RESULTS AND DISCUSSION}

A significant positive linear relationship $\left(\mathrm{R}^{2}=0.4\right.$, $\mathrm{n}=26, p<0.001)$ was found between water alkalinity and calcite precipitation rates, suggesting that the importance of this process is significantly higher with increasing alkalinity (Fig. 1a). No significant effect of chlorophyll-a and total phosphorus on calcification rates was found and including these variables with alkalinity in a multiple linear regression only decreased the strength of the model $\left(\mathrm{R}^{2}=0.34, p<0.05\right)$. However, in lakes, spontaneous calcification is unlikely to occur. Rather, it is mediated by picoplankton that promote the chemical environment necessary for calcification by increasing the $\mathrm{pH}$ and by offering ideal nucleation sites (Obst et al., 2009). The absence of any significant effect of chlorophyll- $a$ and total phosphorus concentrations could be due to the fact that calcite saturation is more determined by alkalinity than by production of the system. The strength of primary production to promote calcification likely depends on the level of calcite saturation which is directly related to water alkalinity. A quantile regression using the
$95 \%$ quantile suggests an alkalinity threshold for calcification at $\sim 1 \mathrm{meq} / \mathrm{L}$ (Fig. 1a), below which calcification is unlikely to occur. This is consistent with the threshold of $1 \mathrm{meq} / \mathrm{L}$ reported in previous studies (Marcé et al., 2015; McConnaughey \& Whelan, 1997). Considering that $57 \%$ of the global area occupied by lakes and reservoirs have alkalinity values above $1 \mathrm{meq} / \mathrm{L}$ (Marcé $e t$ al., 2015), pelagic calcite precipitation is likely to occur in most lakes and reservoirs around the globe. In addition, the $5 \%$ quantile regression indicates that virtually all lakes with alkalinity beyond $2.5 \mathrm{meq} / \mathrm{L}$ will show summer pelagic calcification (Fig. 1a).

Calcite precipitation and dissolution reactions imply changes on both alkalinity and the relative abundance of (DIC) species (Ridgwell \& Zeebe, 2005) (1).

$$
\begin{aligned}
& \mathrm{Ca}^{2+}+2 \mathrm{HCO}^{3-} \leftrightarrow \mathrm{CaCO}_{3}+\mathrm{CO}_{2}+\mathrm{H}_{2} \mathrm{O} \\
& \text { equation (1) }
\end{aligned}
$$

Whereby calcite precipitation releases one mole of $\mathrm{CO}_{2}$ per mole of calcite precipitated, increasing $\mathrm{pCO}_{2}$. Because of the higher calcification rates found in lakes of higher alkalinity, one would expect the increase in $\mathrm{pCO}_{2}$ caused by calcification to be stronger in such systems. However, the ratio between calcite precipitation and $\mathrm{CO}_{2}$ release (commonly referred to as $\Psi)$ depends on the capacity to buffer changes in $\mathrm{pCO}_{2}$ (Frankignoulle et al., 1994; Smith \& Mackenzie, 2016). As a result, the buffering capacity of high alkalinity lakes mitigate $\mathrm{pCO}_{2}$ increase preventing most of the released $\mathrm{CO}_{2}$ to escape to the atmosphere (Fig. 1b). Therefore, the potential change in $\mathrm{pCO}_{2}$ caused by calcite precipitation on a daily time scale is minimal (Fig. 1b).

We used the alkalinity - calcification rates relationship together with the global distribution of lakes and reservoirs per alkalinity level (Marcé et $a l ., 2015$ ) for upscaling calcite precipitation rates to the entire globe. The resulting annual global rate of calcite precipitation of $0.03 \mathrm{Pg} \mathrm{C} \mathrm{yr}^{-1}$ (range $0.01-0.07 \mathrm{Pg} \mathrm{C} \mathrm{yr}^{-1}$ ) is comparable in magnitude to global annual rates of $\mathrm{OC}$ burial of $0.15 \mathrm{Pg} \mathrm{C} \mathrm{yr}^{-1}$ (range $0.06-0.25 \mathrm{Pg} \mathrm{C} \mathrm{yr}^{-1}$, (Mendonça et al., 2017), Fig. 2a). Global calcite precipitation would thus be of the same order of 


\section{Global Pelagic Calcification in Lakes}

magnitude as OC burial, making them both similarly relevant as main drivers of $\mathrm{C}$ cycling in lakes. As a comparison, the average areal calcification rates in lakes (13.8 $\mathrm{g} \mathrm{C} \mathrm{m}^{-2} \mathrm{yr}^{-1}$, range: $5.4-28$, Supplementary Data File) correspond to $37 \%(14 \%-75 \%)$ of areal rates of pelagic calcification in oceans $\left(37 \mathrm{~g} \mathrm{C} \mathrm{m}^{-2} \mathrm{yr}^{-1}\right)$ (Smith \& Mackenzie, 2016).

The net role of pelagic calcification as a sedimentary inorganic carbon sink depends on calcite dissolution during sedimentation and in the sediments. In open oceans $80 \%$ of all carbonate that precipitates dissolves within the water column or in the sediments (Ridgwell \& Zeebe, 2005). Although some studies have reported calcite dissolution in some lakes (Ohlendorf \& Sturm, 2001; Ramisch et al., 1999), others report no dissolution during settling of calcite crystals (Stabel, 1986). A study on 13 lakes revealed that calcite dissolution in lakes and reservoirs is minor compared to calcite precipitation because rather than dissolving in the hypolimnion, calcite tends to accumulate in the sediments (Müller et al., 2016), thereby acting as a long-term $\mathrm{C}$ sink. These results are in agreement with another study on 5 lakes that reports calcite precipitation with no evidence of calcite dissolution (Lenz et al., 2018). Yet, high rates of calcite dissolution are reported in deeper stratified systems rich in OC where decomposition of organic matter promotes anoxic conditions and low $\mathrm{pH}$ in the hypolimnion (Ohlendorf \& Sturm, 2001) and where calcite crystals may partly dissolve in the water column during sedimentation (Ramisch et al., 1999). The global calcification rate provided in this study is a gross estimate to be further built upon. The role of calcite dissolution needs to be assessed at a global scale to determine the net burial flux, which is beyond the scope of this study. Considering calcification alone, the total export of calcite to the sediments would represent between $10 \%$ and $70 \%$ of the total net oceanic sink for pelagic calcification (0.1 Pg C yr-1) (Sabine \& Tanhua, 2010). So long as calcite dissolution hasn't been estimated at a global scale, these values remain hypothetical. This is even more uncertain in the context of global change which is likely to increase the frequency of anoxic conditions in the hypolimnion of stratified systems (Jankowski et al., 2006;
Schwefel et al., 2016) which could promote ideal conditions for calcite dissolution. Nevertheless, these values highlight the disproportionately important role of calcite precipitation in lakes and reservoirs as a potential carbon sink despite the relatively small area that these water bodies occupy on the globe.

The gross estimate of global $\mathrm{CO}_{2}$ emissions caused by calcification is $0.0002 \mathrm{Pg} \mathrm{C} \mathrm{yr}^{-1}$ (range: $0.00005-0.0007 \mathrm{Pg} \mathrm{C} \mathrm{yr}^{-1}$ ). This is an irrelevant fraction of the total $\mathrm{CO}_{2}$ emissions from lakes and reservoirs $(<0.5 \%$, Fig. 2b). Our results contrasts with those of saline lakes where calcite precipitation is expected to contribute significantly to $\mathrm{CO}_{2}$ emissions (Duarte et al., 2008). The low contribution of calcification-derived $\mathrm{CO}_{2}$ emissions is because higher rates of calcite precipitation are found in lakes of higher alkalinity (Fig. 1) that have a stronger capacity to buffer changes in $\mathrm{pCO}_{2}$. Recent studies found that inorganic processes including DIC loading from chemical weathering and calcite precipitation are important drivers of $\mathrm{CO}_{2}$ emissions in lakes and reservoirs (Marcé et al., 2015; McDonald et al., 2013). Our results suggest that pelagic calcite precipitation represents a minor share of emissions caused by inorganic sources (Fig. 2b).

It is important to mention that pelagic calcification rates reported here are probably only a share of total calcification in lakes and reservoirs. Benthic primary production can account for a large fraction of the overall metabolism of lakes (Cremona et al., 2016), and benthic habitats dominated by calcifying macrophytes can promote daily losses of up to $0.57 \mathrm{meq} / \mathrm{L}$ of alkalinity due to intense calcification (Andersen et al., 2017). In the absence of a global estimate of lake benthic calcification we can only speculate about its relevance, but considering potentially high calcification rates from benthic macrophytes (McConnaughey \& Whelan, 1997) and their prevalence in lakes, we posit benthic calcification could be even higher than pelagic. Furthermore, our global estimate only accounts for calcification during the summer season assuming that this represents the largest part within a year. While calcification usually occurs mainly in the summer season, it is variable in time and the possibility of its occurrence in other seasons cannot be excluded (Trapote 


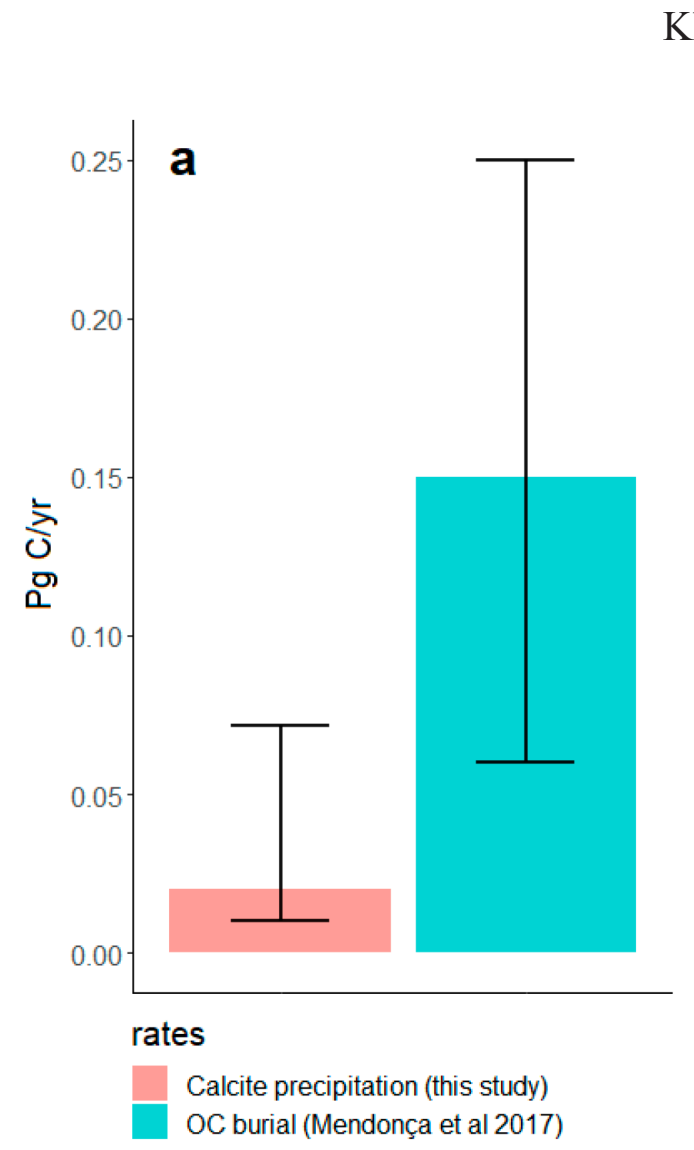

Khan et al.

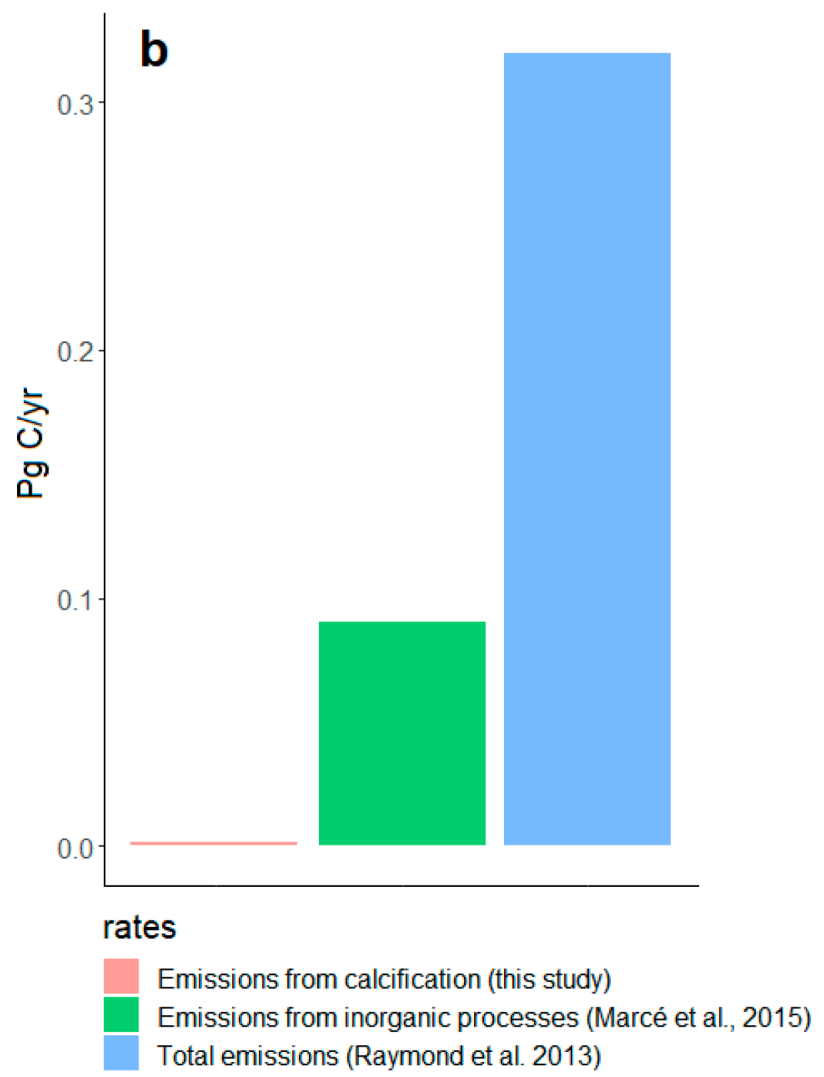

Figure 2. Global rates of calcification and $\mathrm{CO}_{2}$ emissions. (a) Global annual rates of calcite precipitation (this study) and $\mathrm{OC}$ burial (Mendonça et al., 2017) in lakes and reservoirs. The error bars represent the range. (b) Global rates of $\mathrm{CO}_{2}$ emissions from calcification (this study), inorganic processes (Marcé et al., 2015) and total emissions (Raymond et al., 2013). Tasas globales de calcificación y emisiones asociadas de $\mathrm{CO}_{2}$. (a) Tasas globales anuales de precipitación de calcita y enterramiento de carbono orgánico en lagos y embalses. Las barras de error representan el rango. (b) Tasas globales de emisiones de $\mathrm{CO}_{2}$ en lagos asociadas a la calcificación (este estudio), procesos inorgánicos (Marcé et al., 2015) y emisiones totales (Raymond et al., 2013).

et al., 2018). The seasonality of calcification is likely to be directly related to the seasonality of primary production since calcification in lakes is a biologically mediated process that is enhanced during peaks of primary production (Obst et al., 2009). Arriving at a mechanistic understanding of how primary production promotes calcification within the physicochemical context of a lake, including its alkalinity level, is a next step to predict calcification events in lakes and further refine its global estimation by integrating seasonality at a finer scale.

While $\mathrm{CO}_{2}$ emissions caused by calcite precipitation is minor at a global scale, $\mathrm{CO}_{2}$ release during summer calcification can have significant implications on $\mathrm{C}$ dynamics at a local scale, resulting in imbalances between metabolic rates and $\mathrm{C}$ concentrations (Khan et al., 2020). Such imbalances can reach a point where lakes are simultaneously in an autotrophic state, yet they emit $\mathrm{CO}_{2}$ to the atmosphere, as is likely the case in approximately one third of lakes in the boreal region and in the contiguous United States (Bogard \& Giorgio, 2016; McDonald et al., 2013). Accounting for the role of calcite precipitation on $\mathrm{C}$ dynamics at a local scale is necessary to improve the reliability and predictability of lake models that are currently unable to explain the reported imbalances between metabolism and $\mathrm{C}$ fluxes $(\mathrm{Lu}$ et al., 2018). 


\section{Global Pelagic Calcification in Lakes}

To conclude, the rates provided here highlight the role of pelagic calcite precipitation as an important component of the $\mathrm{C}$ cycle in lakes and reservoirs and the need to account for it in global C budgets (Marcé \& Obrador, 2019). Research should aim at quantifying the ratios between production and calcification rates as well as between calcite precipitation and $\mathrm{CO}_{2}$ release along alkalinity gradients in order to account for this process in models of inland water $\mathrm{C}$ processing. Temporal patterns of calcite precipitation and environmental conditions for its occurrence need to be investigated for predicting this process at short and longer temporal scales. Finally, calcite precipitation and dissolution in lakes and reservoirs need to be understood in the context of climate change predictions in order to assess their role as potential $\mathrm{C}$ sinks or $\mathrm{C}$ sources in a changing climate.

\section{ACKNOWLEDGMENTS}

This study was funded by MANTEL ITN (Management of climatic extreme events in lakes and reservoirs for the protection of ecosystem services) through European Union's Horizon 2020 research and innovation program under the Marie Skłodowska-Curie grant agreement No 722518, by the Estonian Research Council grant (PUT PSG32), and by the project C-HYDROCHANGE (CGL2017-86788-C3-3-P and CGL2017-86788C3-2-P) funded by the Spanish Ministry of Science, Innovation and Universities.

\section{DATA AVAILABILITY STATEMENT}

All calcification rates collected from the literature are compiled in the Supplementary Data Excel file, available at http://www.limnetica.net/en/ limnetica. The calculations for the global upscaling of calcification rates and its associated $\mathrm{CO}_{2}$ emissions are presented in this same data Excel file. The code that was used for calculating the effect of calcification on $\mathrm{CO}_{2}$ partial pressure is available online (http://hdl.handle.net/2445/172489).

\section{REFERENCES}

Andersen, M. R., Kragh, T., \& Sand-Jensen, K. (2017). Extreme diel dissolved oxygen and carbon cycles in shallow vegetated lakes. Proceedings of the Royal Society B: Biological Sciences, 284(1862). DOI: 10.1098/ rspb.2017.1427

Bogard, M. J., \& Giorgio, P. A. (2016). The role of metabolism in modulating $\mathrm{CO}_{2}$ fluxes in boreal lakes. Global Biogeochemical Cycles, 30, 1509-1525. DOI: 10.1002/2016GB005463

Cole, J. J., Prairie, Y. T., Caraco, N. F., McDowell, W. H., Tranvik, L. J., Striegl, R. G., Duarte, C. M., Kortelainen, P., Downing, J. A., Middelburg, J. J., \& Melack, J. (2007). Plumbing the global carbon cycle: Integrating inland waters into the terrestrial carbon budget. Ecosystems, 10(1), 171-184. DOI: 10.1007/s10021-0069013-8

Cremona, F., Laas, A., Arvola, L., Pierson, D., Nõges, P., \& Nõges, T. (2016). Numerical exploration of the planktonic to benthic primary production ratios in lakes of the Baltic Sea catchment. Ecosystems, 19(8), 1386-1400. DOI: $10.1007 / \mathrm{s} 10021-016-0006-\mathrm{y}$

Duarte, C. M., \& Prairie, Y. T. (2005). Prevalence of heterotrophy and atmospheric $\mathrm{CO}_{2}$ emissions from aquatic ecosystems. Ecosystems, 8(7), 862-870. DOI: 10.1007/s10021-005$0177-4$

Duarte, C. M., Prairie, Y. T., Montes, C., Cole, J. J., Striegl, R., Melack, J., \& Downing, J. A. (2008). $\mathrm{CO}_{2}$ emissions from saline lakes: A global estimate of a surprisingly large flux. Journal of Geophysical Research, 113(4). DOI: 10.1029/2007JG000637

Frankignoulle, M., Canon, C., \& Gattuso, J. -P. (1994). Marine calcification as a source of carbon dioxide: Positive feedback of increasing atmospheric $\mathrm{CO}_{2}$. Limnology and Oceanography, 39(2), 458-462. DOI: 10.4319/lo.1994. 39.2.0458

Hartley, A. M., House, W. A., Callow, E. M., \& Leadbeater, B. (1995). The Role of a Green Alga in the Precipitation of Calcite and the Coprecipitation of Phosphate in Freshwater. Internationale Revue Der Gesamten Hydrobiologie Und Hydrographie, 80, 385-401. DOI: 10.1002/iroh.19950800302

Jankowski, T., Livingstone, D. M., Bührer, H., Forster, R., \& Niederhauser, P. (2006). Consequences of the 2003 European heat wave for 
Khan et al.

lake temperature profiles, thermal stability, and hypolimnetic oxygen depletion: Implications for a warmer world. Limnology and Oceanography, 51(2), 815-819. DOI: 10.4319/lo.2006. 51.2.0815

Kelts, K., \& Hsü, K. J. (1978). Freshwater Carbonate Sedimentation. Lakes, 295-323. DOI: 10.1007/978-1-4757-1152-3_9

Khan, H., Laas, A., Marcé, R., \& Obrador, B. (2020). Major effects of alkalinity on the relationship between metabolism and dissolved inorganic carbon dynamics in lakes. Ecosystems, 23, 1566-1580. DOI: 10.1007/s10021020-00488-6

Kirillin, G., Hochschild, J., Mironov, D., Terzhevik, A., Golosov, S., \& Nützmann, G. (2011). FLake-Global: Online lake model with worldwide coverage. Environmental Modelling and Software, 26(5), 683-684. DOI: 10.1016/j. envsoft.2010.12.004

Lenz, S., Gruenert, U., Geist, J., Stiefel, M., Lentz, M., \& Raeder, U. (2018). calcite production by calcifying green alga Phacotus lenticularis. Journal of Limnology, 77(2), 209-219. DOI: 10.4081/jlimnol.2018.1692

Lewis Jr, W. (2011). Global primary production of lakes: 19th Baldi Memorial Lecture. Inland Waters, 1(1), 1-28. DOI: 10.5268/IW-1.1.384

Lu, W., Wang, S., Yeager, K. M., Liu, F., Huang, Q., Yang, Y., Xiang, P., Lü, Y., \& Liu, C. (2018). Importance of considered organic vs. inorganic source of carbon to lakes for calculating net effect on landscape $\mathrm{C}$ budgets. Journal of Geophysical Research: Biogeosciences, 123, 1302-1317. DOI: 10.1002/2017JG004159

Marcé, R., \& Obrador, B. (2019). Reuniting biogeochemistry with ecology and evolution. Science, 366(6467), 805-806. DOI: 10.1126/ science.aaz9096

Marcé, R., Obrador, B., Josep-Anton Morguí, Riera, J. L., López, P., \& Joan, A. (2015). Carbonate weathering as a driver of $\mathrm{CO}_{2}$ supersaturation in lakes. Nature Geoscience, 8, 107-111. DOI: 10.1038/NGEO2341

McConnaughey, T. A., \& Whelan, J. F. (1997). Calcification generates protons for nutrient and bicarbonate uptake. Earth-Science Reviews, 42(1-2), 95-117. DOI: 10.1016/S00128252(96)00036-0
McDonald, C. P., Stets, E. G., Striegl, R. G., \& Butman, D. (2013). Inorganic carbon loading as a primary driver of dissolved carbon dioxide concentrations in the lakes and reservoirs of the contiguous United States. Global Biogeochemical Cycles, 27(2), 285-295. DOI: 10.1002/gbc. 20032

Mendonça, R., Müller, R. A., Clow, D., Verpoorter, C., Raymond, P., Tranvik, L. J., \& Sobek, S. (2017). Organic carbon burial in global lakes and reservoirs. Nature Communications, 8(1), 1-6. DOI: 10.1038/s41467-017-01789-6

Millero, F. J. (1979). The thermodynamics of the carbonate system in seawater. Geochimica et Cosmochimica Acta, 43(10), 1651-1661. DOI: 10.1016/0016-7037(79)90184-4

Müller, B., Meyer, J. S., \& Gächter, R. (2016). Alkalinity regulation in calcium carbonate-buffered lakes. Limnology and Oceanography, 61(1), 341-352. DOI: 10.1002/lno.10213

Obst, M., Wehrli, B., \& Dittrich, M. (2009). $\mathrm{CaCO} 3$ nucleation by cyanobacteria: laboratory evidence for a passive, surface-induced mechanism. Geobiology, 7(3), 324-347. DOI: 10.1111/j.1472-4669.2009.00200.x

Ohlendorf, C., \& Sturm, M. (2001). Precipitation and dissolution of calcite in a Swiss high Alpine lake. Arctic, Antarctic, and Alpine Research, 33(4),410-417.DOI:10.1080/15230430.2001. 12003449

Ramisch, F., Dittrich, M., Mattenberger, C., Wehrli, B., \& Wüest, A. (1999). Calcite dissolution in two deep eutrophic lakes. Geochimica et Cosmochimica Acta, 63(19-20), 3349-3356. DOI: 10.1016/S0016-7037(99)00256-2

Raymond, P. A., Hartmann, J., Lauerwald, R., Sobek, S., McDonald, C., Hoover, M., Butman, D., Striegl, R., Mayorga, E., Humborg, C., Kortelainen, P., Dürr, H., Meybeck, M., Ciais, P., \& Guth, P. (2013). Global carbon dioxide emissions from inland waters. $\mathrm{Na}$ ture, 503(7476), 355-359. DOI: 10.1038/ nature 12760

Ridgwell, A., \& Zeebe, R. E. (2005). The role of the global carbonate cycle in the regulation and evolution of the Earth system. Earth and Planetary Science Letters, 234(3-4), 299-315. DOI: $10.1016 /$ j.epsl.2005.03.006

Rodrigo, M. A., Vicente, E., \& Miracle, M. R. 


\section{Global Pelagic Calcification in Lakes}

(1993). Short-term calcite precipitation in the karstic meromictic Lake La Cruz (Cuenca, Spain). SIL Proceedings, 25, 711-719.

Sabine, C. L., \& Tanhua, T. (2010). Estimation of anthropogenic $\mathrm{CO}_{2}$ inventories in the ocean. Annual Review of Marine Science, 2(1), 175198. DOI: 10.1146/annurev-marine-120308080947

Schwefel, R., Gaudard, A., Wüest, A., \& Bouffard, D. (2016). Effects of climate change on deepwater oxygen and winter mixing in a deep lake (Lake Geneva): Comparing observational findings and modeling. Water Resources Research, 52(11), 8811-8826. DOI: 10.1002/2016WR019194

Smith, S. V., \& Mackenzie, F. T. (2016). The role of $\mathrm{CaCO} 3$ reactions in the contemporary oceanic $\mathrm{CO}_{2}$ cycle. Aquatic Geochemistry, 22(2), 153-175. DOI: 10.1007/s10498-015-9282-y
Stabel, H.-H. (1986). Calcite precipitation in Lake Constance: Chemical equilibrium, sedimentation, and nucleation by algae. Limnology and Oceanography, 31(5), 1081-1093. DOI: 10.4319/1o.1986.31.5.1081

Trapote, M. C., Vegas-Vilarrúbia, T., López, P., Puche, E., Gomà, J., Buchaca, T., Cañellas-Boltà, N., Safont, E., Corella, J. P., \& Rull, V. (2018). Modern sedimentary analogues and integrated monitoring to understand varve formation in the Mediterranean Lake Montcortès (Central Pyrenees, Spain). Palaeogeography, Palaeoclimatology, Palaeoecology, 496, 292304. DOI: 10.1016/j.palaeo.2018.01.046

Woolway, R. I., \& Merchant, C. J. (2019). Worldwide alteration of lake mixing regimes in response to climate change. Nature Geoscience, 12(4), 271-276. DOI: 10.1038/s41561-0190322-x 